\title{
Attributes of God in Ephesians: Meaning and relevance
}

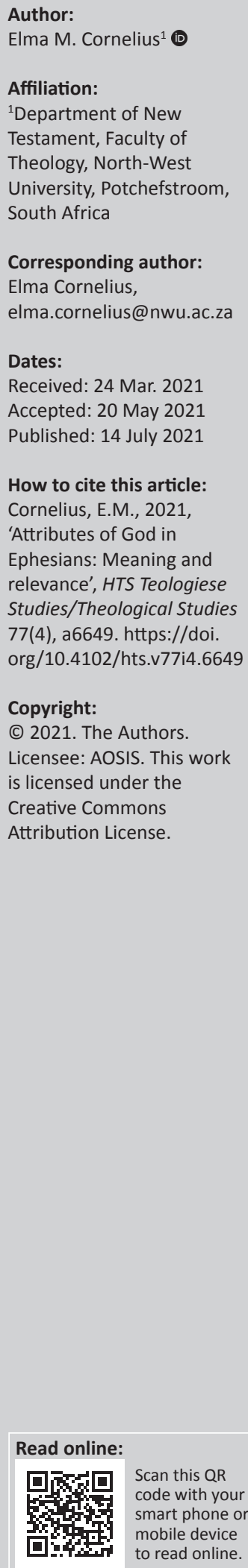

Who is God according to the author of the letter to the Ephesians? What does this letter communicate about the character of God? Which attributes of God are specifically in focus in Ephesians? The focus of this article is the meaning and relevance of these characterisations of God in the letter structure, in the argumentation, in the rhetoric of the author and in the sociohistorical context of the author and readers. The method of interpretation includes word studies, the epistolographic structure, the argumentation, the socio-historical background and the persuasion strategies used in the letter. The author identifies and categorises all attributes of God in Ephesians within the structure of the letter and argumentation and shows how these contribute to the purpose of the letter. The author of Ephesians presents God as being in total control of the universe, willing to be mankind's Father and to equip them with wisdom and strength and gifts and blessings and he exhorts them to trust this God and imitate Him in their behaviour.

Contribution: Although the attributes of God have been discussed by various scholars, this article is an attempt to not only identify the attributes of God in the letter to the Ephesians, but also to discuss the meaning and relevance of these in this letter.

Keywords: Ephesians; attributes of God; communicable; incommunicable; relevance.

\section{Introduction}

Who is God according to the author of the letter to the Ephesians? What does this letter communicate about the character of God? Which attributes of God are specifically in focus? Why does this letter communicate these specific attributes of God? What have scholars written about the attributes - the characteristics - of God in Ephesians so far? When we talk about the attributes of God, we are trying to answer questions such as: Who is God, What is God like and What kind of God is He?

The author of this article plans to research the qualities distinctive to God as found in Ephesians and the role of the mentioning of these qualities in the letter. The first step is to find and research scholarly works on the attributes of God as communicated in general in the Bible, as well as in Ephesians. The second step is to identify, discuss and classify the characteristics of God as it is communicated in Ephesians in particular. The focus will be on the meaning and relevance of these characterisations of God in the letter structure, in the argumentation, in the rhetoric of the letter's author and in the socio-historical context of the author and readers.

The method of interpretation will include word studies, the epistolographic structure, the argumentation, the socio-historical background and the persuasion strategies used in the letter.

\section{What do other scholars say?}

Different categories of the attributes of God in the Bible are identified and discussed by different scholars:

- Barth (1957) does not use the word 'attributes' but refers to the 'divine perfections' of God. The perfections are divided into six dyads, three perfections under 'divine love' and three perfections under 'divine freedom'.

- Bavinck (1979) distinguishes between communicable attributes (those that human beings can also have) and incommunicable attributes (those that belong to God alone).

- Erickson (1985) distinguishes between attributes about the greatness and attributes about the goodness of God.

- Macleod (1991) identifies two main categories: infinite powers and personality attributes.

- Grudem (1994) wrote a systematic theology and covered the character of God in Chapters 11-16 where he distinguishes between 'communicable' attributes and 'incommunicable' attributes of God. 
- Frame (2013) uses a threefold classification that reflects God's control, authority and presence. He distinguishes between attributes of love, knowledge and power and then interfaces these with classifications of control, authority and presence.

The attributes of God in Ephesians will be categorised into the two categories of 'communicable' and 'incommunicable' attributes - those attributes of God shared with or transferred to or transmitted to human beings and those exclusive to God. This article will add to the above by showing how these attributes in Ephesians feature in the different letter parts as part of different persuasion strategies, contributing to the overall theme and purpose of the letter.

\section{Communicating the character of God in Ephesians}

What does the author of Ephesians communicate about God the Father, His Son Jesus and the Holy Spirit? Before this becomes the focus in the article, the socio-historical background, relevant for this study, is addressed first.

\section{The socio-historical background of Ephesians}

The authorship of Ephesians has been disputed for many years (see Fowl 2012:9-28 for a detailed discussion of this dispute and its relevance for interpretation). An interpretation of the relevance and meaning of the attributes of God as presented in the letter, however, does not depend on the question of authorship. Therefore, for the sake of this article, the author is identified as 'Paul, the apostle' (as found in the letter opening in 1:1). In this article, the attributes of God as communicated by the author (whether Paul or a follower of Paul) will be the focus.

When interpreting the meaning and relevance of the attributes of God in Ephesians, it will be kept in mind that this letter was probably not written as a response to particular circumstances (see Arnold 2010; Gundry 2012:461; Thielman 2010:19). Thielman (2010:20) is, however, of the opinion that 'the letter does express concern for its readers on specific topics' in 1:18-23, 3:17-19, 4:1-19 and 5:3-18, which could be an indication of the 'weariness in the readers' commitment to the gospel'.

The focus on the communication of the attributes of God in Ephesians and the warning in the relevant pericope (4:17-5:21) in 4:17 to no longer live like the gentiles do, who are separated from the life of God, necessitates a study of the religious culture of Ephesus as well as the imperial cult of those times. Heine (2002:77-78) explains that the environment in which Christians in Ephesus had to live was haunted by demons, troubled by magic and controlled by idolatry. Friesen (2001:61) adds that the Ephesians worshiped not only the gods but also the emperor. Thielman (2010:20-21) reminds us of the role Artemis played in Ephesus. Artemis was the goddess of fertility, and Ephesus was the centre for Artemis worship. Worship of the gods and the emperor was a prominent feature of life in Ephesus, and it is against this socio-historical background that one needs to study the communication about God in the letter to the Ephesians. The church as 'body of Christ' (4:1-16; see Gundry 2012:461) is exhorted to no longer live as the gentiles do.

The author of a letter can teach about the character of God in any part of the letter structure, contributing to the overall theme and purpose of the letter, and it can be used as the persuasion strategy of logos [to state a fact about God] or as ethos [to persuade the readers about the character of the author] or as pathos [to affect the emotions of the readers]. ${ }^{1}$ To make a conclusion in the end about the relevance and meaning of the attributes of God in Ephesians, the focus of this section is on the being and character of God in each letter part.

\section{The attributes of God in the letter opening}

Cohick (2013:27) remarks that the opening chapter of Ephesians serves to magnify God. This is true when one realises that God is revealed right from the start in the letter opening, in the identification of the author, as well as in the greeting. Christ is referred to as the One who sends people

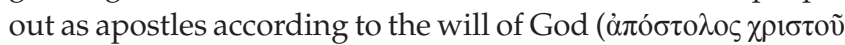

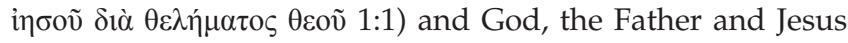

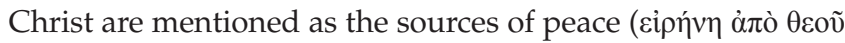

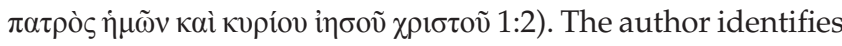
himself as an apostle and immediately mentions that there is a relationship between himself, Jesus Christ and God. When Paul acknowledges that he owes his position to a divine commission, he presents himself as a representative or ambassador of God (Klein et al. 2006). The genitive $\chi \rho ı \tau \tau o \tilde{~}$ inбoṽ can be interpreted to indicate source, possessor or even subject. He is a person who was sent by Jesus Christ, coming from Jesus Christ, being owned by Jesus Christ and sent by

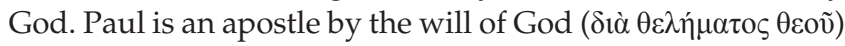
- what he does is part of God's plan. The author uses this reference as the persuasion strategy ${ }^{2}$ of ethos, ${ }^{3}$ where he persuades his readers of his own identity in terms of his relationship with God. Then, when he greets the readers, he greets them with a typical synagogue greeting 'grace and peace from God our Father and Jesus Christ'. Paul greets his readers by wishing them grace and peace, coming from a dual source (Klein et al. 2006), 'God our Father and the Lord Jesus Christ'. Jesus is Christ and Lord, and Klein et al. (2006) say that Paul applies this divine title to Jesus showing that he is the exalted and transcendent one. Both God and Christ are the sources of an undeserved divine favour (grace) and peace.

Paul deemed it necessary to devote 12 verses in the letter opening to praise God. O'Brien (1999:93) says the opening words of the doxology in 1:3 are 'an outburst of praise to God'. With this doxology, the author uses the persuasion

1.See Kennedy [1994] for a discussion of classical rhetoric.

2.See Aristotle (1947), Ars Rhetorica 1,2:3-6, for a discussion of these persuasion strategies. The three persuasion strategies, as originally defined by Aristotle, are used in tandem in all forms of communication to be able to communicate effectively.

3.Ethos is a strategy used to persuade the reader or audience of the character of the speaker or author. 
strategies of ethos, $\log o s^{4}$ and pathos. ${ }^{5}$ On the one hand, he says something about his own character (ethos), namely that he knows God and that he is willing to praise Him. On the other hand, he provides information (logos) about God and reminds the readers of what they already know about God. O'Brien (1999:93) says Paul wishes to evoke a 'cognitive response in the readers' by reminding them of their experience of salvation. However, Paul also affects the emotions of the readers (pathos) when he reminds them of who God is to them. Swindoll $(2015: 168)$ says it is meant to motivate the readers to be 'good' - to behave in 'holiness and blamelessness' before Him.

When Paul gives praise to God in this section (1:3), he refers to God as the Father of Jesus Christ, who blessed us in the heavenly realms with every spiritual blessing in Christ (1:3) and as the source of grace - something he gives freely in the one He loves (1:6). Paul speaks of the riches of God's grace

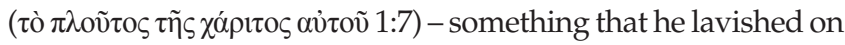
us with all wisdom and understanding (1:8). In this doxology, three statements are made in total about God in general, one statement about Jesus and one about the Holy Spirit:

- God 'chose us in Him, before the creation of the world to be holy and blameless by predestining us to be adopted':

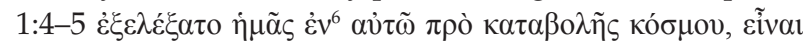

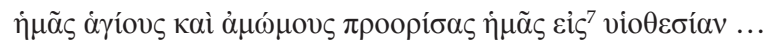

- God, 'making known to us the mystery of His will... to bring all things in heaven and on earth together in Christ':

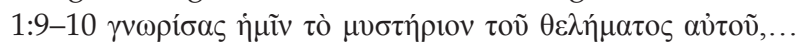

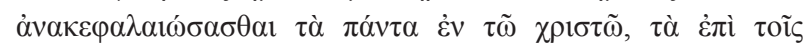

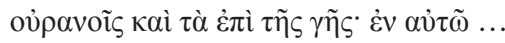

- God 'in whom we were chosen, having been predestined according to the plan of His will so that we might be for

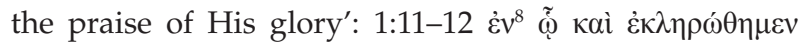

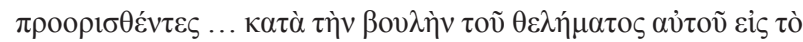

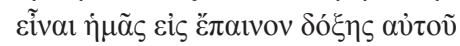

- Jesus 'in whom we have redemption and forgiveness through his blood because of God's grace': 1:7 غ่v ${ }^{9} \tilde{\omega}$ है $\chi 0 \mu \varepsilon v$

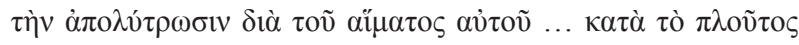

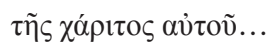

- The 'Holy Spirit who was promised, who is a deposit ${ }^{10}$ guaranteeing our inheritance': 1:13-14 ... $\tau \tilde{\omega} \pi v \varepsilon v ́ \mu \alpha \tau \imath \tau \tilde{\eta} \varsigma$

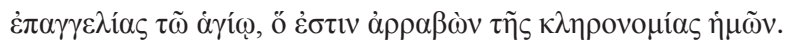

Paul motivates his praise for God with a statement in 1:4-5 that God chose us in Him, before the end of the world

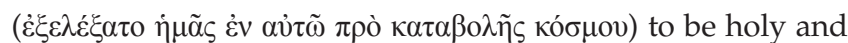
4.Logos implies the use of logic to persuade people.

5.Pathos is used to affect the emotions of the readers or audience. Cohick (2013:41) states that Paul's eulogy serves to inform even as it praises. Although Cohick does not identify the persuasion strategies of logos and pathos, she still acknowledges the same functions.

6.See Cohick (2013:43) about how the author uses prepositional phrases to help govern the meaning.

7.See footnote 6 .

8.See footnote 6 .

9.See footnote 6

10.Cohick (2013:42) explains this 'deposit' of the Holy Spirit as securing the promises of the salvation.

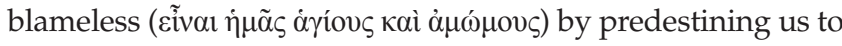

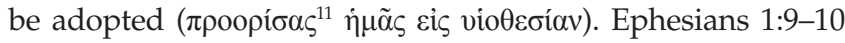
mentions the mystery of His will and 1:11 is a statement about the plan and will of God. Thielman (2010:74) shows how different words pile up upon another in verse 11 to emphasise

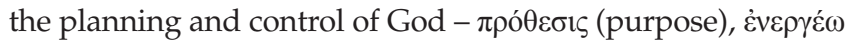

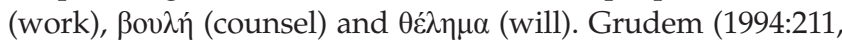
213) says this will is God's free will in general - His hidden plan for the future (Grudem 1994:215). Grudem (1994:211) explains that God's will is 'that attribute of God whereby he approves and determines to bring about every action necessary for the existence and activity of himself and all creation'. God's will concerns God's choices of, for example, predestining us to be adopted (1:4-5) and creating us with the purpose to glorify Him (1:11-12). Grudem (1994:162, 213) explains that God decided (out of His free will) to create and save us for His own glory. Arnold (2010) says this plan of God was a 'masters plan for redemption'. This is all about God's will, and with these statements about the will of God, the author uses the persuasion strategies of logos and pathos not only to inform and remind his readers about this fact and attribute of God but also to affect them emotionally by providing them with the security of God being in control and to warn them not to attempt to be God themselves.

The last part of the letter opening, the thanksgiving (1:15-23), is an example of the author's use of the persuasion strategies of pathos, ethos and logos. By giving thanks to God already at the beginning of the letter, he affects the emotions of the readers and persuades them of his relationship with God, his sincerity, his care and his compassion for them - he thanks God for the readers' faith and asks Him to give them wisdom and revelation and enlighten their minds. In all of this, the author does this by stating facts about God. In this thanksgiving, Paul makes various references to the nature and character of God:

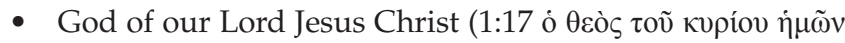

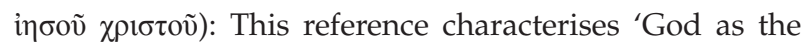
Christian God', says Lincoln (1990:56). According to O'Brien (1999:129), this expression functions to remind the reader that God has blessed believers in the Lord Jesus Christ.

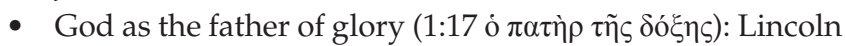
(1990:56) explains that this glory denotes the splendour of God's power and presence.

- God who gives 'a spirit of wisdom and revelation in the

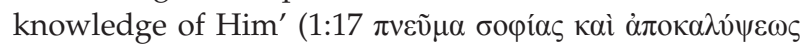

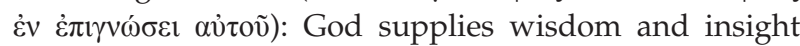
(Lincoln 1990:56).

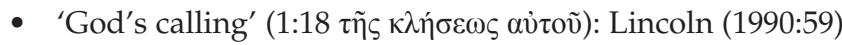
says the language of 'calling' brings to mind choice, predestination and appointment. This is about 'God's initiative in bringing a person into relationship with himself' (Lincoln 1990:59).

- God's 'incomparable greatness' of His power for those

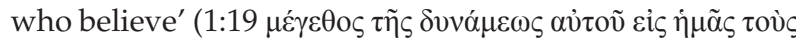
$\pi 1 \sigma \tau \varepsilon v ́ o v \tau \alpha \varsigma)$.

11.Cohick (2013:42) shows how Paul describes God's actions by focusing on verbs (usually participles) 
- God who 'raised Jesus from the dead and seated him in

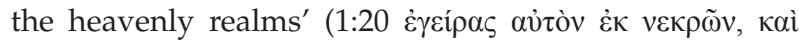

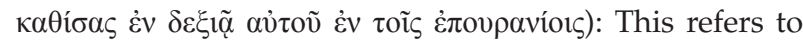
what God accomplished in Christ.

- God who 'placed all things under the feet of Jesus and appointed him to be the head to the church over everything'

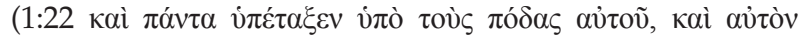

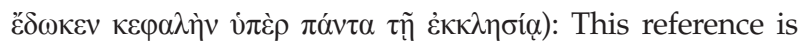
used to denote 'Christ's position of rule and authority over all things' (Lincoln 1990:70)/God exalted Christ to a 'position of power and authority' (Lincoln 1990:79).

The letter openings of ancient letters (like the exordium of speeches) served to introduce the author, address the readers and make the readers studious and favourable towards the author and receptive for what follows in the letter body (see Aristotle 1947:xiv; Quintilian 1947). In the letter opening of Ephesians, the author communicates that life is all about God and not only does he show that even he himself has a relationship with God, but he also acknowledges that the readers are in a relationship with God. When Paul focuses on his and the readers' relationship with God, he assures them that God is the One with power who predestines, plans, chooses, calls and sends out believers. Paul gives hope by describing the power, peace, grace, blessings and wisdom coming from God. Paul already makes clear the relationship between God the Father, His Son and the Holy Spirit when he proclaims that God is the father of Jesus, who sees Jesus as the head of the church, who gave His Spirit as a deposit for believers' inheritance. The letter opening makes it clear that both author and readers are already in a relationship with a powerful God who already planned their lives and that Jesus is the head of them as church.

What does the author want to teach or exhort the readers in the arguments in the main part of the letter, namely the letter body?

\section{The letter body}

The letter body can be divided into three sections - opening, middle and closing. The opening of the letter body functions like the narration (see Aristotle 1947:xvi; Quintilian 1947) (background of the arguments) and the proposition (see Quintilian 1947) (statement of argument) in speeches. The middle of the letter body contains the main arguments (argumentation [see Aristotle 1947:xvii; Quintilian 1947]) of the letter. The closing of the letter fulfils the role of the peroration (see Aristotle 1947:xix; Quintilian 1947), which is a summary and final attempt to persuade the readers.

\section{Letter body opening}

In the body opening of the letter, three teachings and a doxology are apparent:

- Sinfulness and salvation 2:1-10,

- Paul is a preacher to the gentiles 3:1-1,

- Peace and unity 2:11-22 and

- Prayer 3:14-21.
Teaching about sinfulness and salvation 2:1-10: In this first argument, a contrast between the believers' past and present situation is identified. It is stated that by nature, 'we are

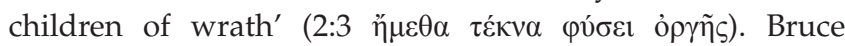
(1984:284) says this expression means that the believers are 'worthy to receive divine judgement'. Paul thus states that the believers are by nature subject to the wrath of God. This denotes the believers' past situation of trespasses and sin, characterised by 'death, bondage, and condemnation' (see Lincoln 1990:117). However, this argument also states that humankind's hopelessness of existence in alienation from God (see Bruce 1984:285) was changed by God. Lincoln (1990:92) refers to it as a 'turning point in history'. This argument in the letter body opening serves this function by using the persuasion strategies of logos and pathos to express the change occasioned for believers in God's power and actions in Christ. It is stated on the one hand as a fact that

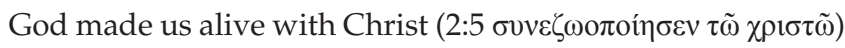
and that he raised us up with Christ and seated us with him

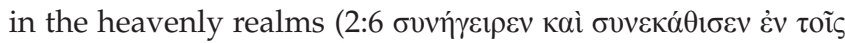
$\dot{\varepsilon} \pi$ ovpavíors). Different references are made to God: being rich

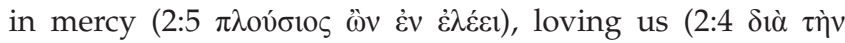

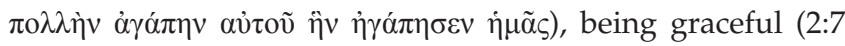

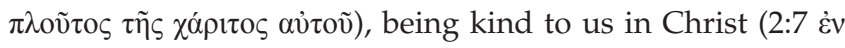

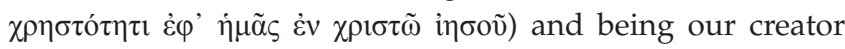

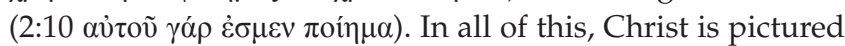
as the 'mediator through whom the change for humanity has been established', says Lincoln (1990:119). Although this argument uses the persuasion strategy of logos, it also serves to persuade the readers to act upon these facts. It also serves as an appeal addressed to both the minds and emotions of the readers when they become aware of how much they owe God. An awareness of God's salvation power prepares the readers for what follows in the rest of the letter body (see Lincoln 1990:91).

Teaching about peace and unity 2:11-22: In this argument, the author states as motivation for why the readers who were once separated from Christ have been brought back,

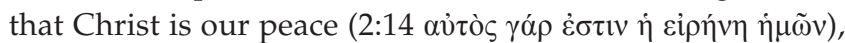
and he explains this statement by making references to

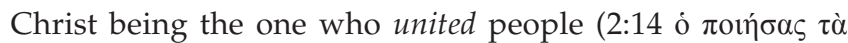
$\left.\dot{\alpha} \mu \varphi \tau_{\tau \varepsilon \rho \alpha} \tilde{\varepsilon} v\right)$ and destroyed the dividing wall of hostility (2:14

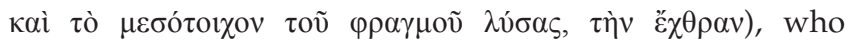

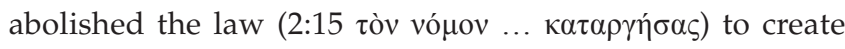
one, new human out of the two by making peace (2:15 ivo

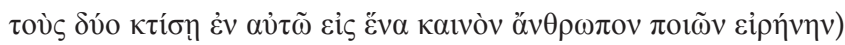

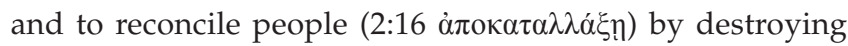
hostility (ả making more statements about Christ: He preached peace

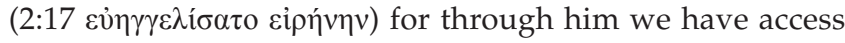

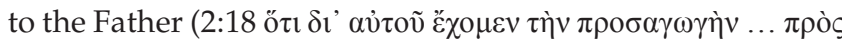
$\tau$ òv $\pi \alpha \tau \dot{\varepsilon} \rho \alpha)$. Whilst the author mentions the fact that the readers are members of God's household, he mentions Christ as the cornerstone of this household (2:20 obvo

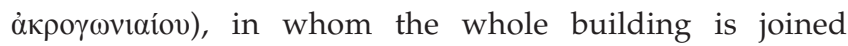

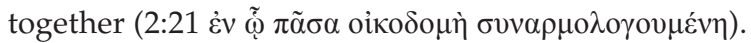


Teaching about Paul as a preacher to the gentiles 3:1-13: In this argument, the author explains why he was preaching to the gentiles. Lincoln (1990:xliii) sees this argument as 'a reminder of the readers' debt to Paul and his ministry'. The 'mystery of Christ' (tò $\mu$ orńpıov) is mentioned in 3:3-4. The author mentions this mystery to explain why he preaches to the gentiles in his argument in 3:7-14. Verse 3:6 states that this mystery is that both gentiles and Israel share in the promise of Jesus Christ. God is thus fair. In the one body of Christ, diverse people became united. In 3:7, Paul states that

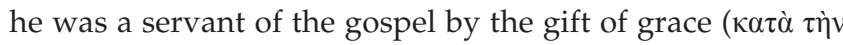

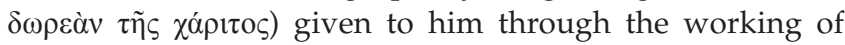

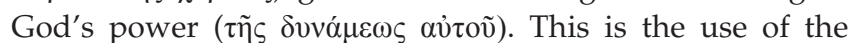
persuasion strategy of pathos as Paul makes a call on the readers' emotions to be positive towards him as a preacher when they realise he was only acting in God's will.

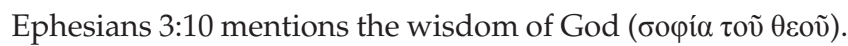
'In his extraordinary wisdom', Arnold (2010) says, 'God was able to design a way to deal with' the problem of sin. Two references to the plans of God are made in this argument. In 3:9, a reference is once again made to the mystery ( $\mu v \sigma \tau \eta \dot{p i o v)}$ of God, who created all things. In 3:11, another reference is

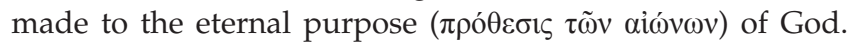
Grudem (1994:164) explains that these verses show that God had plans for all eternity. Ephesians refers to it as the eternal purpose or mystery of God. This is about God's 'counsel and hidden plans' (Grudem 1994:215). This is thus another example of God's will, and the author mentions this attribute of God as a motivation for why he was preaching to the gentiles - thus the persuasion strategy of logos. In another way, it is also an example of pathos as Paul affects the readers' emotions in order for them not to judge him but to accept him as a preacher in God's will. He also mentioned this at the very beginning of the letter in 1:1 when he introduced himself as an apostle according to the will of God.

Prayer and doxology 3:14-21: The prayer in these verses communicates that God is universal father and creator of all: in verse 14-15, Paul refers to the Father ( $\pi \alpha \tau \dot{\eta} \rho)$ from whom every family on earth and in heaven derives its name. Lincoln (1990:203) says this expression immediately makes one think of Psalm 147:4 and Isaiah 40:26, where God's calling the stars by name shows Him as their Creator. In Paul's requests to this father, we become aware of God who can strengthen ( $\kappa \rho \alpha \tau \alpha \omega \theta \tilde{\eta} v \alpha)$ humans through

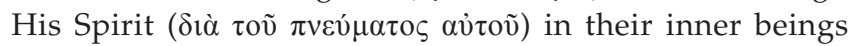
(3:16). References are also made in 3:18-19 to the love ( $\dot{\alpha} \alpha \dot{\pi} \eta)$ of Christ - a love that surpasses all knowledge

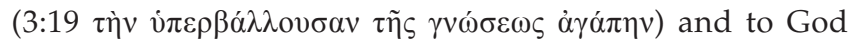
who is able to do immeasurably more than one can

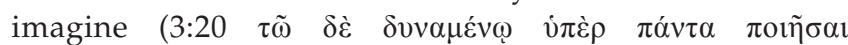
$\dot{v} \pi \varepsilon \rho \varepsilon \kappa \pi \varepsilon \rho 1 \sigma \sigma o \tilde{v} \tilde{\omega} v$ aitov́ $\mu \varepsilon \theta \alpha$ iे vooṽ $\mu \varepsilon v)$. The prayer in itself serves the strategies of ethos and pathos when persuading the readers of his sincerity and his relationship with God. One cannot miss, however, the fact (logos) stated when Paul gives all glory to God - he states that God is One who is able to do immeasurably more than we can ask or imagine (3:20).

\section{The letter body middle}

In the letter body middle, the author exhorts the readers to change their behaviour. One can identify six arguments in this section:

- live a life worthy of your calling (4:1-16),

- live as children of the Light (4:17-5:21),

- exhortations to wives and husbands (5:22-33),

- exhortations to children and parents (6:1-4),

- exhortations to slaves and masters (6:5-9) and

- put on God's armour (6:10-18).

The only exhortation in this letter part not to portray any attributes of God is the exhortations to parents and children in $6: 1-4$.

Live a life worthy of your calling (4:1-16): In this exhortation, the author urges the readers to live a life worthy of the calling they have received and he gives particular instructions. He inter alia instructs them to keep the unity, and it is then when he refers to God as the Father of all, who is over all and

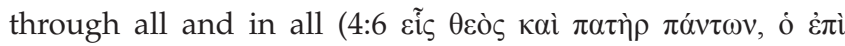

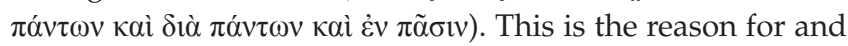
logic behind being united - the fact that there is only one God, being the Father of all. Contributing to this unity, Paul mentions the gift proportioned to believers by Christ (4:7). The quotation of Psalm 68:18 in 4:8 stating that God gave

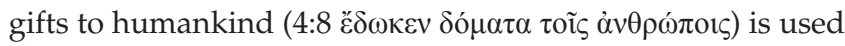
as a reference to the ascension of Christ and his bestowal of gifts on the church (see Frame 2013:343). Verse 12 explains that the purpose of Christ's giving of gifts was to prepare God's people for the works of service so that the church may be built up. The arguments show that the diversity of gifts by Christ contributes to the unity amongst believers (see Lincoln 1990:225). These diverse gifts are meant to equip believers so that they can grow into unity and spiritual adulthood. It is stated in 4:15 that believers will grow up into Him who is the head, namely Christ.

Live as children of the Light 4:17-5:21: When the author encourages his readers to live as children of the Light, he inter alia warns them in 4:30 not to grieve the Holy Spirit

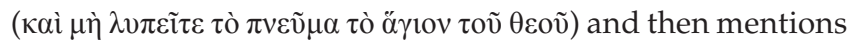
the Holy Spirit in 4:30 as the one for whom the readers were sealed ( $\dot{\varepsilon} \nu \tilde{\omega} \dot{\varepsilon} \sigma \varphi \rho \alpha \gamma i \sigma \theta \eta \tau \varepsilon)$ for the day of redemption. The author aims at the emotions of his readers when he warns them: those who live like the gentiles do, grieve the Holy Spirit of God. Lincoln (1990:307) explains that the Spirit authenticates believers as God's people. One of the encouragements in this argument is to forgive and then

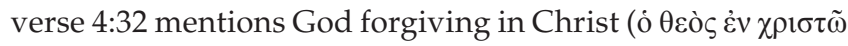

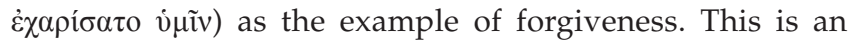
example of the use of the persuasion strategy of logos as the author reminds them of a factual reality of God's forgiveness. In 5:1-2, another example of logos is found when Paul encourages the readers to be imitators of God and to live a life of love in 5:1-2 and then mentions the love

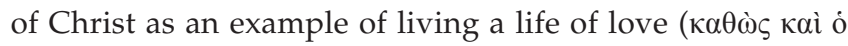




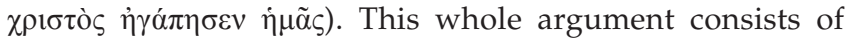
commands on how to live as children of the Light, and in 5:6 he warns them of the wrath of God (i o $\rho \gamma \eta \dot{~} \tau o \tilde{v} \theta \varepsilon \circ \tilde{)})$ that will come on those who are disobedient. When Paul warns his readers in 5:15 to be careful of how they live, he commands them in 5:17 to understand what the Lord's will ( means asking for His will. This is a command based on logical facts.

Exhortations to wives and husbands 5:22-33: In the exhortations to the husbands and wives, Christ is referred to as the example for the husband and wife's behaviour. The husband is the head of the wife just as Christ is the head of

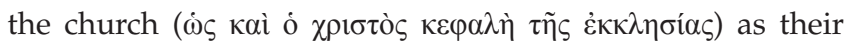

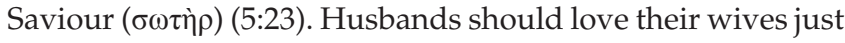

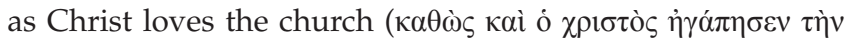

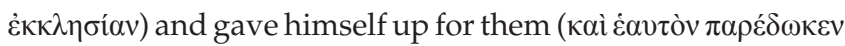

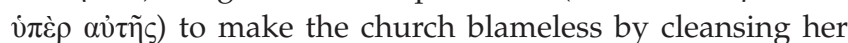

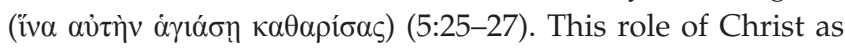
the Saviour is aimed to make the church holy and blameless

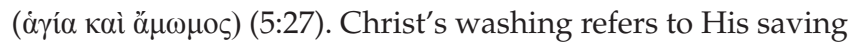
action (see Bruce 1984:388).

Exhortations to slaves and masters 6:5-9: In the exhortations to the slaves and masters, Paul reminds them that the Lord will reward everyone for whatever good he does (6:8). The incentive for good behaviour is God's reward (Klein et al. 2006). What the reward is, is not mentioned, but one can assume it is meant eschatologically. Reminding the readers of the reward serves as the persuasion strategy of pathos as the reward is thrown out as bait for good behaviour. Arnold (2010) says the assurance of God's reward is a motivation for serving with a good attitude and performing good works.

\section{Put on God's armour 6:10-18}

This is the final argument in the letter body middle, encouraging the readers to be strong in the mighty power of

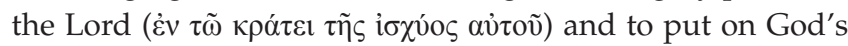
armour. The reference to God's mighty power in 6:10 is, however, more than just a reference. It forms part of the command to be strong and qualifies the word strong. The readers' strength can only be found in the Lord and in His mighty power. This is an example of the use of the persuasion strategy of logos. O'Brien (1999:463) correctly interprets the genitive $\tau$ oṽ $\theta \varepsilon \circ \tilde{v}$ (of God) in 6:10 as a genitive of origin and therefore considers 'the armour of God' as 'the armour that God supplies'. In God's plan thus, He provides the armour to live a new life.

\section{The letter body closing and the letter closing}

In the letter body closing, the author makes last requests in 6:19-20, and no attributes of God are offered. The same applies to the letter closing in 6:21-24.

\section{A summary of the attributes of God in Ephesians}

The Trinity, God the Father, His Son Jesus Christ and the Holy Spirit find their way into this letter. The following attributes of God can be summarised.

\section{God's control and power}

References to God's control and power run throughout the letter. Paul uses the following words to describe God's power and control (see Table 1).

In the letter opening, in the doxology where he specifically praises God for who He is, Paul finds it necessary to remind the readers of the fact that God is in control and to secure (see Swindoll 2015:161) them emotionally by knowing this. God's control is described as the 'mystery of God's will' (1:9-10), and for the readers it meant that God predestined their lives (1:4-5 and 1:11). Ephesians 1:11 mentions the plan of God's will ( explains that the $\beta$ ov $\lambda \eta$ refer to God's 'intelligent deliberation', whilst $\theta \varepsilon \dot{\lambda} \eta \mu \alpha$ refers to God's will, which proceeds from his deliberation.

When Paul introduces himself as the author of the letter in the letter opening, he mentions this same fact by mentioning that even he was an apostle through the will of God (1:1). Then, when Paul discusses his own preaching to the gentiles in the letter body opening, he once again refers to the fact that he is preaching through the working of God's power (3:7) and that he was preaching to the gentiles because he understood something of God's mystery, namely that the gentiles were coheirs with the Israelites $(3: 3-4)$. And then twice, he refers once again to the mystery of God (3:9) and God's eternal purpose (3:11). The reference in 3:20 is almost conclusive to what he has said so far about God - God can do immeasurably more than we can ask or imagine. And when Paul exhorts his readers in the letter body middle, he mentions God's power and will in two commands:

- understand what the Lord's will is (5:17) and

TABLE 1: Words used to describe God's power and control.

\begin{tabular}{|c|c|}
\hline Words used by Paul & Meaning according to Louw and Nida (eds. 1988) \\
\hline$\Theta \varepsilon \dot{\lambda} \eta \mu \alpha$ & $\begin{array}{l}\text { Things happen according to what God desires (see eds. Louw } \\
\text { \& Nida 1988:289) }\end{array}$ \\
\hline 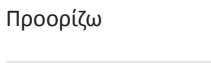 & $\begin{array}{l}\text { God decides upon things ahead of time (see eds. Louw \& } \\
\text { Nida 1988:360) }\end{array}$ \\
\hline к $\lambda \tilde{n ̃ \sigma \iota \varsigma}$ & $\begin{array}{l}\text { God calls and 'urgently invites' humans to act in a certain way } \\
\text { (see eds. Louw \& Nida 1988:424) }\end{array}$ \\
\hline 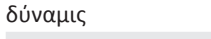 & God has power (see eds. Louw \& Nida 1988:680) \\
\hline 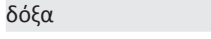 & The greatness of God (see eds. Louw \& Nida 1988:736) \\
\hline Muotńpıov & God is mysterious (eds. Louw \& Nida 1988:345) \\
\hline 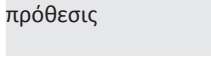 & $\begin{array}{l}\text { God has a purpose and can plan in advance (see eds. Louw \& } \\
\text { Nida 1988:358) }\end{array}$ \\
\hline Кра́tos & $\begin{array}{l}\text { God has the power to rule or control (see eds. Louw \& Nida } \\
1988: 681 \text { ) }\end{array}$ \\
\hline íxúc & $\begin{array}{l}\text { God has an exceptional capability and strength (see eds. } \\
\text { Louw \& Nida 1988:676) }\end{array}$ \\
\hline
\end{tabular}


- be strong in the Lord and in his power and put on His armour (6:10). What does Ephesians communicate about the power and control of God?

- The immensity of God's power,

- God controls this world,

- God's plan and will for this world - referred to as the mystery of God's will and His eternal purpose and

- God predestines humankind.

Frame (2013:21) discusses the control and power and will of God as attributes and says that the Bible reveals God as the One who controls all the forces of nature and history and he uses the expression 'the Lord's sovereign rule'. God's power, he proceeds (Frame 2013:345), works according to His will. Ephesians does indeed communicate God to be the One who controls the history of all, One with an immense power who acts according to His will. This attribute is called 'omnipotence' and 'sovereignty'.

God's will, Grudem (1994:211) explains, 'is that attribute of God whereby he approves and determines to bring about every action necessary for the existence and activity of himself and all creation'. Grudem also differentiates between the 'secret will' of God and His 'revealed will' (Grudem 1994:213). Ephesians refers to God's will in both categories (see Table 2).

The characteristic to have power, to exercise control and to make choices is something that one can also find in humans. However, God's kind of power and control and will is high above humankind's abilities. Therefore, this attribute is still classified under a godly attribute because God's power is clearly an ability, which is proverbially impossible for humankind to equal.

\section{God as the source of peace}

In the greeting in the letter opening, the author makes a statement about God's grace when he greets them with

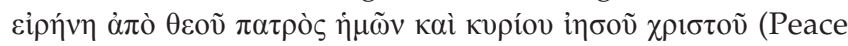
from God our Father and the Lord Jesus Christ). This statement about the peace of God serves the functions of the persuasion strategies of ethos, pathos and logos. Not only does the author persuade his readers of the fact that God is the source of peace $(\log o s)$, but he also persuades them that he as the author knows this God (ethos) and that he cares about them enough to wish them this peace (pathos). Grudem (1994:203) defines God's peace as the fact that, 'in God's being and in his actions, he is separate from all confusion and disorder', being 'continually active in wellordered, fully controlled, simultaneous actions'.

TABLE 2: References in Ephesians to God's will.

\begin{tabular}{ll}
\hline God's revealed will & God's secret will \\
\hline $\begin{array}{l}\text { 1:1 Paul is an apostle through } \\
\text { God's will }\end{array}$ & $\begin{array}{l}\text { 1:9-10 He made known to us the mystery of His } \\
\text { will }\end{array}$ \\
$\begin{array}{ll}\text { 5:17 Seek the will of the Lord } \\
\text { (see Grudem 1994:214) }\end{array}$ & $\begin{array}{l}\text { 1:11 Chosen, having been predestined according } \\
\text { to the plan of him who works out everything in } \\
\text { conformity with the purpose of his will (Grudem } \\
\text { 1994:215) } \\
\text { 3:3-4 The mystery made known to me by } \\
\text { revelation }\end{array}$ \\
\hline
\end{tabular}

\section{God as the giver of grace}

God's grace means, according to Grudem (1994:200), 'God's goodness toward those who deserve only punishment'. This grace is 'never obligated but is always freely given on God's part'. This free goodness of God is wished upon the readers in the letter opening and then referred to as a fact about God. When Paul presents himself to the readers as a servant of God by God's grace in 3:7, he uses the fact of God's grace to let the reader realise that he was in the service of God.

\section{God has mercy}

If one reads Louw and Nida's (eds. 1988:751) explanation of the word č $\lambda \varepsilon \circ \varsigma$ (2:5), it is clear that God has the potential to show kindness or concern for human beings.

\section{Love of God}

In Ephesians, we find references to God's love for humankind (2:4 and 5:25-27) - God loves 'us' and the 'church'. This love for humankind is a saving love: ${ }^{12}$

- God made 'us' alive with Christ because of this love (2:4-5).

- When husbands are instructed to love their wives (5:25), Christ's love is given as an example of love where $\mathrm{He}$ gave himself up for the 'church'.

Through God's love, humankind was saved. His love is 'salvation from $\sin ^{\prime}$, says Frame (2013:240). It is this love that surpasses all knowledge (3:19), and it is this love that should be imitated by humankind (5:1-2). Grudem (1994:198) describes this love as 'self-giving for the benefit of others'. This love of God is only mentioned once in this letter.

\section{Wrath of God}

God intensely hates sin - from there His wrath. In the argument about the contrast between sinfulness and salvation, the readers are reminded about the fact of the wrath of God, but the argument is not aimed at fearing God's wrath. Although they are children of wrath by nature (Ephesians 2:3), salvation freed them from this wrath (Ephesians 2:4-11). In 5:6, the wrath of God is stated to warn the readers. The wrath of God is thus only a reality for non-believers.

\section{Wisdom of God and the One who supplies wisdom}

Right at the beginning of the letter, in the doxology, the author refers to the way God gives grace - through wisdom and understanding, by having 'insight' (see eds. Louw \& Nida 1988:385). Wisdom is not only God's way of doing things, but $\mathrm{He}$ is also the giver and revealer of wisdom.

\section{God unites}

In the argument on peace and unity (2:11-22), the readers are reminded of God's role in this peace and unity -

12.See Frame (2013:239-241) for a discussion of God's saving love 
namely to unite people, to destroy the wall of dividing, to join together, to destroy hostility. In the next argument where Paul explains why he preached to the gentiles, he explains the mystery that God united Israel and the gentiles (3:6).

\section{God as Giver of blessings}

God is the Father who spared nothing when it came to blessing his people spiritually (see Klein et al. 2006). These blessings are 'in' Christ - these blessings come through Christ. The reference to 'the heavenly realms' as the place where believers are blessed should be understood metaphorically. Klein et al. (2006) explain that this reference is more likely soteriological and eschatological. Although the Ephesians are not yet in their heavenly dwelling (see Fowl 2012), God's blessings stretch into the heavenly realms - a reality for believers, because of Christ.

\section{God's redemption and forgiveness in Christ}

God is the One who brings about the adoption of believers and $\mathrm{He}$ does it through Christ. This adoption implies forgiveness by God's grace through the blood of Christ. The outcome of this is new lives for believers and the promise to be seated with Him in the heavenly realms and receiving the Spirit. The Spirit is their assurance of their redemption (Fowl 2012:50). This process of redemption is an ongoing state for the believers (Fowl 2012:43).

\section{God is kind}

God's grace materialises as 'kindness' (Klein et al. 2006), and his kindness is displayed in the life, death and resurrection of Jesus (see 2:7). Fowl (2012:77) says this kindness of God is a manifestation of God's constant and abiding character. Paul refers to God's kindness only once in the argument on the contrast between the readers' past situation of sinfulness and the current situation of salvation. He says God raised us up with Christ to show His grace, expressed in his kindness. He not only refers to the fact of God's kindness but also aims at affecting the emotions of his readers with the power to move them to be thankful to God.

\section{God is the Father of all}

God as the Father is referred to twice in this letter. In the prayer in the letter body opening, Paul addresses his prayer on behalf of the Ephesians to God the Father. With this reference, he acknowledges God as the Father of all believers and confirms the fact of God's relationship with believers as a father but also aims at affecting the readers' emotions by letting them feel safe. In the exhortation to live as children of the Light, Paul commands the readers to keep the unity of the Spirit, and to explain his command, he elaborates on the fact of one body, one Spirit, one hope, one Lord and one Father.

\section{God strengthens}

Paul prays to God to strengthen the Ephesians and hereby acknowledges God's potential to do exactly that through His Spirit. Lincoln (1990:206) says this is a request to God to vitalise and strengthen believers through His Spirit in those parts of them that are not accessible to sight but which are open to His energising influence.

\section{God rewards}

In the exhortations to the slaves and masters, Paul commands the slaves inter alia to serve wholeheartedly and he motivates this command with the statement and promises that God will reward everyone for whatever good they do. He uses the fact of a God who will reward, to affect the Ephesians emotionally with a promise to move them to obedience to this command.

\section{The attributes of God in Christ}

Already in the letter opening, it is made clear that God is the

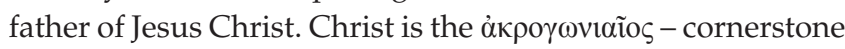
or important stone of the building, which is the church

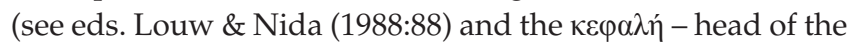
church used in the figurative sense (see eds. Louw \& Nida 1988:95). Christ is the Saviour and through Him the world is saved - giving the readers of Ephesians a reason to live a new life. Christ sacrificed himself for the church - it is an outreach of Jesus the Son to humankind. The love of Christ is to be imitated by the readers - a love that 'surpasses all knowledge'. In Christ, believers receive grace, gifts and peace. In the letter body opening, when he discusses peace and unity, the author shows them that because Christ is our peace (2:14), and because his purpose was making peace (2:15), as he was teaching peace $(2: 17)$ - all logical facts $(\log o s)$ - the readers' status changed.

\section{The attributes of God in the Spirit}

God is ever present in the lives of believers through His Spirit.

\section{A classification of the attributes of God in Ephesians}

In an attempt to classify the above attributes of God as they feature in Ephesians, it becomes clear that classification is not so straightforward and can never claim to be perfect. No attribute of God is completely communicable, and no attribute of God is completely incommunicable. We can be wise, but we can never be as wise as God. We can express and experience love, but we will never be infinitely loving like God. Really, we should say that 'communicable' attributes are the ones that are somewhat shared with us. It is almost easier to distinguish between God's greatness and His goodness or between attributes of power and attributes of personality. The following is the author's classification of the attributes of God in Ephesians (see Table 3). 
TABLE 3: Classification of the attributes of God in Ephesians.

\begin{tabular}{|c|c|c|}
\hline $\begin{array}{l}\text { Attribute of } \\
\text { God }\end{array}$ & Featuring in letter & Used in persuasion \\
\hline \multicolumn{3}{|c|}{ Incommunicable attributes of God communicating God's greatness and power } \\
\hline $\begin{array}{l}\text { Power and } \\
\text { control }\end{array}$ & $\begin{array}{l}\text { Right through the letter - from the } \\
\text { letter opening to the letter body }\end{array}$ & $\begin{array}{l}\text { Stated and referred to as a } \\
\text { fact and to supply the readers } \\
\text { with a sense of security and } \\
\text { hope and a reason to believe. } \\
\text { This attribute of God is the } \\
\text { foundation for every } \\
\text { command in the letter. }\end{array}$ \\
\hline $\begin{array}{l}\text { The source } \\
\text { of peace }\end{array}$ & $\begin{array}{l}\text { In the greeting, the author wishes } \\
\text { his readers a peace coming from God. } \\
\text { Then in the letter body opening in the } \\
\text { argument on peace and unity, it is } \\
\text { stated that Christ is the giver and } \\
\text { preacher of peace. }\end{array}$ & $\begin{array}{l}\text { Paul wishes his readers peace } \\
\text { from God - a fact used to } \\
\text { persuade the readers of Paul's } \\
\text { caring relationship with them. } \\
\text { In the letter body opening, it } \\
\text { is part of logical reasoning. }\end{array}$ \\
\hline $\begin{array}{l}\text { Redeemer } \\
\text { and Saviour }\end{array}$ & $\begin{array}{l}\text { Throughout the letter, God's } \\
\text { redemption in Christ and the Holy } \\
\text { Spirit is mentioned. In the argument } \\
\text { on the husbands and wives, Christ is } \\
\text { mentioned as Saviour and as the One } \\
\text { who gave Himself up for the church. }\end{array}$ & $\begin{array}{l}\text { God's redemption in Christ } \\
\text { and Christ being the Saviour } \\
\text { who gave Himself up are facts } \\
\text { mentioned to affect the } \\
\text { readers emotionally to have } \\
\text { hope and faith. }\end{array}$ \\
\hline $\begin{array}{l}\text { The head and } \\
\text { cornerstone } \\
\text { of the church }\end{array}$ & $\begin{array}{l}\text { Christ is mentioned as being } \\
\text { appointed as the head of everything, } \\
\text { of the household and of the church in } \\
\text { the letter opening and in the letter } \\
\text { body opening and middle. }\end{array}$ & Stated as a fact. \\
\hline Father of all & $\begin{array}{l}\text { Twice in this letter a reference is made } \\
\text { to God as Father of all - once in the } \\
\text { letter body opening and once in the } \\
\text { letter body middle. }\end{array}$ & $\begin{array}{l}\text { The fact of God's fatherhood } \\
\text { to all provides the reader } \\
\text { with a sense of security. }\end{array}$ \\
\hline $\begin{array}{l}\text { Father of } \\
\text { Christ }\end{array}$ & $\begin{array}{l}\text { Right in the opening of the letter, in } \\
\text { the doxology and thanksgiving, God is } \\
\text { referred to as the father of Christ. }\end{array}$ & This is mentioned as a fact. \\
\hline $\begin{array}{l}\text { Giver of } \\
\text { blessings } \\
\text { and gifts }\end{array}$ & $\begin{array}{l}\text { Only in the letter opening in the } \\
\text { doxology, God is mentioned as the } \\
\text { giver of blessings. In one argument } \\
\text { in the letter body, Christ is } \\
\text { mentioned to be the giver of gifts. }\end{array}$ & $\begin{array}{l}\text { Mentioned as a fact about } \\
\text { God the Father and Christ. }\end{array}$ \\
\hline $\begin{array}{l}\text { Giver of } \\
\text { wisdom }\end{array}$ & $\begin{array}{l}\text { In the letter opening in the } \\
\text { thanksgiving }\end{array}$ & $\begin{array}{l}\text { The fact of God's giving of } \\
\text { wisdom is mentioned. }\end{array}$ \\
\hline $\begin{array}{l}\text { Strengthening } \\
\text { humans }\end{array}$ & $\begin{array}{l}\text { God is mentioned as One who can } \\
\text { strengthen human beings in their inner } \\
\text { beings through the Holy Spirit, only once } \\
\text { in this letter in the prayer. }\end{array}$ & $\begin{array}{l}\text { Mentioning God as One who } \\
\text { can strengthen humans is the } \\
\text { use of a fact to give humans } \\
\text { hope emotionally. }\end{array}$ \\
\hline \multicolumn{3}{|c|}{ Communicable attributes of God's personality } \\
\hline Grace & $\begin{array}{l}\text { Throughout the letter, references are } \\
\text { made to God as the giver of } \\
\text { undeserved grace, also in Christ. }\end{array}$ & $\begin{array}{l}\text { This is referred to as a fact for } \\
\text { believers. }\end{array}$ \\
\hline Mercy & $\begin{array}{l}\text { Referred to once in an argument } \\
\text { in the letter body. }\end{array}$ & $\begin{array}{l}\text { The fact of God's mercy is } \\
\text { mentioned. }\end{array}$ \\
\hline Love & $\begin{array}{l}\text { In the letter body opening, a reference } \\
\text { is made to God's love as the reason for } \\
\text { God saving humankind. The love of } \\
\text { Christ is referred to in the prayer in } \\
\text { this letter part, and in two arguments } \\
\text { in the letter body middle, the love of } \\
\text { Christ is used as an example of how to } \\
\text { live in love and of how husbands } \\
\text { should love their wives. }\end{array}$ & $\begin{array}{l}\text { The fact of God's love is used } \\
\text { to affect the readers } \\
\text { emotionally. The love of } \\
\text { Christ is offered as logical } \\
\text { examples of love in this } \\
\text { world. }\end{array}$ \\
\hline Wrath & $\begin{array}{l}\text { In the letter body, the readers } \\
\text { are reminded in two arguments } \\
\text { of the wrath of God. }\end{array}$ & $\begin{array}{l}\text { In the first argument, a } \\
\text { reference is made to the } \\
\text { wrath of God to remind the } \\
\text { readers how lucky they are to } \\
\text { receive salvation from that. In } \\
\text { the second argument, the } \\
\text { readers are warned not to be } \\
\text { deceived as wrath will follow. }\end{array}$ \\
\hline Wisdom & $\begin{array}{l}\text { In the letter opening in the doxology } \\
\text { and in the letter body in one of the } \\
\text { arguments, the wisdom of God is } \\
\text { mentioned. }\end{array}$ & $\begin{array}{l}\text { God wisdom is mentioned as } \\
\text { a fact. }\end{array}$ \\
\hline $\begin{array}{l}\text { Uniting } \\
\text { people }\end{array}$ & $\begin{array}{l}\text { In two arguments in the letter body, } \\
\text { God's role in uniting people is } \\
\text { mentioned. }\end{array}$ & $\begin{array}{l}\text { God's role in uniting people is } \\
\text { mentioned as a fact. }\end{array}$ \\
\hline Forgiving & $\begin{array}{l}\text { In the letter body, God's forgiveness } \\
\text { in Christ is given as an example for } \\
\text { humankind to follow in their } \\
\text { forgiveness of others. }\end{array}$ & $\begin{array}{l}\text { The fact of a forgiving God is } \\
\text { given not only as an example } \\
\text { for humankind to follow but } \\
\text { also to affect the readers } \\
\text { emotionally, making them } \\
\text { feel obliged to forgive others. }\end{array}$ \\
\hline Kind & Mentioned once in the letter body. & $\begin{array}{l}\text { The fact of God's kindness is } \\
\text { referred to move the readers } \\
\text { emotionally to be thankful. }\end{array}$ \\
\hline $\begin{array}{l}\text { Reward } \\
\text { people }\end{array}$ & $\begin{array}{l}\text { In the letter body middle, the fact of } \\
\text { God's willingness to reward people for } \\
\text { whatever good they have done is used } \\
\text { to motivate them to be obedient } \\
\text { to a command. }\end{array}$ & $\begin{array}{l}\text { The fact of God being the } \\
\text { One who will reward people } \\
\text { is used to affect the readers } \\
\text { to be obedient. }\end{array}$ \\
\hline
\end{tabular}

\section{The meaning and relevance of God's attributes in Ephesians}

How do the attributes of God in this letter compare to the attributes of the Roman gods and the emperor who were served by the people in Ephesus? Although the GrecoRoman gods were superior to humankind and did have some differences from human beings (e.g. they were ageless, deathless, not limited to physical restrictions), they were 'anthropomorphic', and their mode of operation was amoral (Ferguson 1987:114, 133). Although these were gods, they had human traits, emotions and intentions, almost the same situation as with the emperors who controlled the people, claimed deity and demanded worship (Gundry 2012:69). The gentiles conducted rituals to receive mercy from the gods and emperors, to keep them happy and to live in peace under their control. People worshiped them out of fear. Sacrifices to these powers, ablutions and other ceremonies purified the people - Ferguson (1987:147) explains that the 'sacrifice was an exchange' with the idea of 'I give in order that you may give to me'. It is against this background that the author of Ephesians presents his God to his readers in his letter. The Ephesians letter offers a kind of security and hope not to be found amongst the Greco-Roman gods. Paul shows his readers that their God is in total control of the universe, willing to be their Father and to equip them. He exhorts them to trust this God and imitate Him in their behaviour.

God's incommunicable attributes are mentioned to prove that God (the Father, His Son and Holy Spirit) is not human - He is powerful, controls the world, $\mathrm{He}$ is the Father of all who strengthens people, gives them blessings, gifts, wisdom, peace and saves and redeems them. This God wants a relationship with people, and in this relationship, his communicable attributes of mercy, love, grace, forgiveness, wisdom and kindness should serve as an example to be imitated. The readers are, however, also warned about God's wrath, but in the same time, His reward is promised to believers.

How do the attributes of God, presented in this letter, contribute to the theme and purpose and the communicative function of this letter (as mentioned before)? It is known that this letter was probably not written as a response to particular circumstances. Bruce (1984:245) sees the purpose of Ephesians as 'to encourage Gentile Christians to appreciate the dignity of their calling'. Right in the opening of the letter, the readers are identified as being 'in Christ' (1:1) and in the thanksgiving, this relationship is set clear-Christ is the head of this church who is His body (1:22).

The letter serves to encourage this body of Christ to live according to this calling - therefore, the main arguments in the letter body middle to exhort the readers to live a life worthy of their calling (4:1-16), to live as children of the Light (4:17-5:21), how to behave as wives and husbands (5:22-33), as children and parents (6:1-4), as slaves and masters (6:5-9) and to put on God's armour (6:10-18): 
In the exhortation to live a life worthy of one's calling (4:1-16), three incommunicable attributes of God are mentioned Him being the Father of all, Christ being the head of the church and God giving gifts to believers. The logic behind this argument is clear: the readers as believers need to live a life worthy of their calling, because they are called and gifted by a supernatural being, God:

- In the exhortation to live as children of the Light (4:17-5:21), God's communicable attributes of forgiveness and love are the examples to follow by the readers. The communicable attribute of God's wrath is set as a warning of what might follow if they are not obedient to the exhortation to live as children of the Light. God's communicable attributes are thus to be followed by the readers.

- In the exhortation to wives and husbands (5:22-33), the attributes of God come in as example for the husband's behaviour - the incommunicable attribute of Christ as the head, His love for the church and the incommunicable attribute of Christ giving Himself up for His church.

- In the exhortation to parents and children (6:1-4), no attribute of God is presented.

- In the exhortation to slaves and masters (6:5-9), however, the readers are reminded of and motivated by the communicable attribute of God who will reward good behaviour.

- The exhortation to put on the armour of God (6:10-20) is an exhortation to the believers to be strong in the Lord and therefore the incommunicable attribute of God's power is mentioned.

But before the exhortations are given, Paul uses the opening of the letter body to first teach the readers some background information to understand the exhortations and he reminds them of his calling to preach to gentiles for them to feel indebted to him. To ensure that the readers will understand the exhortations in the letter body middle, he teaches them about salvation and sinfulness (2:1-10) and peace and unity (2:11-22) and to ensure that the readers will feel indebted to him, he explains his work as a service to God (3:1-13) and to prove his sincerity and relationship with God, he prays to God (3:14-21):

- When Paul explains the contrast between the readers' past of sinfulness and their present situation of salvation (2:1-10), the incommunicable attributes of God as creator, Christ as mediator and God's salvation power (how He made us alive, raised us up and seated us with Christ) are mentioned. God's communicable attribute of wrath is set against His communicable attributes of love, kindness, mercy and grace.

- When Paul explains in 2:11-22 the readers' situation of being one in Christ, he mentions God's incommunicable attributes of being the source of peace and Christ being the cornerstone of the household. The readers' situation was completely changed because of God's communicable attribute of uniting and reconciling people.

- When Paul explains his work amongst the gentiles in 3:1-13, he pictures himself as a servant of God through the grace and power of God - called by God to serve the gentiles - because God is mysterious and fair and has wisdom and an eternal purpose. The three incommunicable attributes relevant for Paul's servanthood amongst the gentiles are the fact that God has power, a mysterious plan and an eternal purpose. Within God's power, Paul serves the gentiles because of God's communicable attributes of uniting people, being fair and having wisdom.

- Chapter 3:14-21 is Paul's prayer to the God who called him - and he glorifies this God as a supernatural being with incommunicable attributes such as being the Father of all, who can do immeasurably more than one can imagine. In Paul's requests to God, the communicable attributes of God who can strengthen and love humans are called upon to assist the readers so that they can have faith and understand the love of God.

But even before the letter body opening (2:1-3:21) in the thanksgiving in 1:15-23, Paul aims at affecting the emotions of the readers and persuades them of his honest relationship with God and with them as readers. When he thanks God for the readers' faith and asks Him to give them wisdom and revelation and enlighten their minds, he reminds them of who their God is - a God that nobody can equal - a God who is the Father of glory with His incomparably power and presence, who can give humans wisdom and revelation in the knowledge of Him, who calls humans into a relationship with Him, the One who raised Jesus and appointed Him as the head over everything. This thanksgiving only focuses on the incommunicable attributes of God.

The doxology (1:3-12) directly after the greeting in the letter opening is Paul's praise for God with exactly the same persuasive power as the thanksgiving. Paul reminds the readers of who God is to affect them emotionally to be willing to live according to His will - in other words to help them have the right attitude for the exhortations to follow in the rest of the letter. It also serves to persuade the readers of Paul's relationship with and knowledge of God. God as a super being is magnified for His incommunicable characteristics such as being the father of Jesus Christ and the source of peace, the God who predestines us, redeems and forgives us, all according to His mysterious will and plan. God is revealed in this doxology as having communicable attributes that can be imitated by human beings: blessing people, having grace, wisdom and understanding.

That is why Paul already magnifies God right from the start in the letter opening by referring to God's incommunicable attributes when he announces himself as an apostle by the will of God, the God who is in control and the source of peace and grace.

\section{Conclusion}

The author of Ephesians presents God as the reason for his being and service to the gentiles, for his writing of the letter, for the being and well-being of the readers and for the readers to live according to His calling. This God has no equal - He is 
the Father of all who has all power and control, things happen according to His will, He saved this world and redeemed all and He is the source of peace, blessings, gifts, wisdom and strength. This God can be followed and imitated by believers in the way He loves, unites people, forgives and shows grace, mercy and kindness.

\section{Acknowledgements Competing interests}

The author declares that she has no financial or personal relationships that may have inappropriately influenced her in writing this article.

\section{Author's contributions}

E.M.C. is the sole author of this research article.

\section{Ethical considerations}

This article followed all ethical standards for research without direct contact with human or animal subjects.

\section{Funding information}

This research received no specific grant from any funding agency in the public, commercial or not-for-profit sectors.

\section{Data availability}

Data sharing is not applicable to this article as no new data were created or analysed in this study.

\section{Disclaimer}

The views and opinions expressed in this article are those of the author and do not reflect the official policy or position of any affiliated agency of the author.

\section{References}

Aristotle, 1947, Ars Rhetorica, Loeb Classical Library, William Heinemann, London.

Arnold, C.E., 2010, Exegetical commentary on the NT: Ephesians, Grand Rapids, MI, viewed 01 March 2021, from https://sierra.nwu.ac.za/record=b2233538 S4

Barth, K., 1957, Church Dogmatics II.1: The doctrine of god, G.W. Bromiley \& T.F. Torrance (eds.), T\&T Clark, Edinburgh.

Bavinck, H., 1979, The doctrine of God, The Banner of Truth Trust, London.

Bruce, F.F., 1984, The epistles to the Colossians, to Philemon, and to the Ephesians, The New International Commentary on the New Testament, William B. Eerdman Publishing Company, Grand Rapids, MI.

Cohick, L.H., 2013, Ephesians: a new covenant commentary, Lutterworth Press, Cambridge, viewed 20 August 2020, from https://sierra.nwu.ac.za/ record=b2039115 $\sim 4$.

Erickson, M., 1985, Christian theology, Baker Books, Grand Rapids, MI.

Ferguson, E., 1987, Backgrounds of early Christianity, William B. Eerdmans Publishing Company, Grand Rapids, MI.

Fowl, S.E., 2012, Ephesians: A commentary, 1st edn., Westminster John Knox Press, Louisville, KY, viewed 19 September 2020, from https://sierra.nwu.ac.za/ record $=$ b2096687-s4.

Frame, J.M., 2013, Systematic theology. An introduction to Christian belief, P\&R Publishing, Phillipsburg, NJ.

Friesen, S.J., 2001, The imperial cults and the Apocalypse of John: Reading revelation in the ruins, Oxford University Press, Oxford.

Gundry, R.H., 2012, A survey of the New Testament, 5th edn., Zondervan, Grand Rapids, MI.

Grudem, W., 1994, Systematic theology, Zondervan, Grand Rapids, MI.

Heine, R.E., 2002, Commentaries of Origen and Jerome on St. Paul's Epistle to the Ephesians, Oxford Early Christian Studies, Oxford University Press, Oxford.

Hoehner, H.W., 2002, Ephesians. An exegetical commentary, Baker Academic, Grand Rapids, MI.

Kennedy, G.A., 1994, A new history of classical rhetoric, Princeton University Press, Princeton, NJ.

Klein, W.W., Garland, D.E., Still, T.D. \& Rupprecht, A.A., 2006, Ephesians, Philippians, Colossians, Philemon, Zondervan, Grand Rapids, MI.

Lincoln, A.T., 1990, Ephesians. World Biblical Commentary, vol. 42, Word Books, Dallas, TX.

Louw, J.P. \& Nida, E.A. (eds.), 1988, Greek-English Lexicon of the New Testament 1\&2, United Bible Societies, New York, NY.

Macleod, D., 1991, Behold your god, Christian Focus Publication, EP Books, Grand Rapids, MI.

O'Brien, P.T., 1999, The Letter to the Ephesians, William B. Eerdmans, Grand Rapids, MI.

Quintilian, 1947, Institutio Oratoria, vol. I-IV, William Heinemann, London.

Swindoll, R.C., 2015, Galatians, Ephesians, Living Insights New Testament Commentary, Tyndale House Publishers, Carol Stream, IL.

Thielman, F., 2010, Ephesians, Baker Exegetical Commentary on the New Testament, Baker Academic, Grand Rapids, MI, viewed 01 March 2021, from https://nwulib. nwu.ac.za/login?url=https://sierra.nwu.ac.za/record=b2405153 S4. 